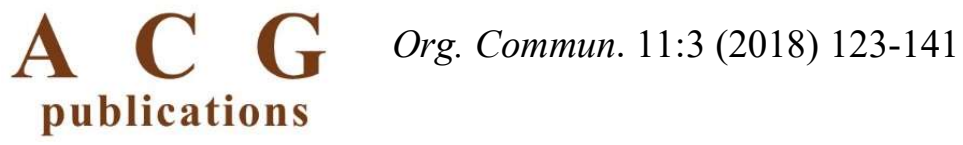

organic communications

\title{
Biohydrogels for medical applications: A short review
}

\section{Yunis Moukbil $\oplus^{1,2}$, Faik Nuzhet Oktar $\oplus^{1,2}$, Burak Ozbek $\oplus^{3,2}$, Denisa Ficai $\odot$ 4,5,6, Anton Ficai ${ }^{5,6,7}$, Ecaterina Andronescu ${ }^{5,6,7}$, Mehmet Sayıp Eroglu $\oplus^{8,9}$ and Oguzhan Gunduz $\oplus^{2,10^{*}}$}

\author{
${ }^{1}$ Bioengineering Department, Faculty of Engineering, Marmara University, Istanbul, Türkiye \\ ${ }^{2}$ Advanced Nanomaterials Research Laboratory, Marmara University, Istanbul, Türkiye \\ ${ }^{3}$ Metallurgical and Materials Engineering, Institute of Pure and Applied Sciences, Marmara University, \\ Istanbul, Türkiye \\ ${ }^{4}$ Politehnica University of Bucharest, Faculty of Applied Chemistry and Material Science, Department of \\ Inorganic Chemistry, Physical Chemistry and Electrochemistry; Gh Polizu street 1-7, 011061 Bucharest, \\ Romania \\ ${ }^{5}$ Politehnica University of Bucharest, Faculty of Applied Chemistry and Material Science, National \\ Centre for Micro and Nanomaterials; Spl. Independentei 313, 060042 Bucharest, Romania \\ ${ }^{6}$ Politechnica University of Bucharest, Faculty of Applied Chemistry and Material Science, National \\ Centre for Food Safety; Spl. Independentei 313, 060042 Bucharest, Romania \\ ${ }^{7}$ Politechnica University of Bucharest, Faculty of Applied Chemistry and Material Science, Department \\ of Science and Engineering of Oxide Materials and Nanomaterials; Gh Polizu street 1-7, 011061 \\ Bucharest, Romania \\ ${ }^{8}$ Chemical Engineering Department, Faculty of Engineering, Marmara University, Istanbul, Türkiye \\ ${ }^{9}$ TUBITAK-UME, Chemistry Group Laboratories, Gebze, Kocaeli, Türkiye \\ ${ }^{10}$ Metallurgical and Materials Engineering, Faculty of Technology, Marmara University, Istanbul, \\ Türkiye
}

(Received June 20, 2018; Revised September 14, 2018; Accepted September 19, 2018)

\begin{abstract}
Hydrogels have been widely used as drug delivery systems for scaffold production (in different soft and hard tissue engineering, including bones), thanks to their biocompatibility and biodegradability. In addition to the possibility of synthesizing a wide range of hydrogels from various natural and synthetic polymers, they are suitable for scaffold production. Moreover, they can have antimicrobial, antitumor and analgesic functions due to their intrinsic properties or through addition of proper biologically active agents. In this article, different types of hydrogels are reviewed alongside their application areas. Different methods are applied for the preparation of hydrogels and their compositions, and are strongly correlated with the morphological and mechanical properties of the synthesized hydrogels, which had a great influence on the performances of the respective scaffolds. The most effective ways to produce the desired scaffolds are mold casting, especially, 3D printing and electrospinning due to the ability to manipulate and control the shape and size of the desired scaffold as well as their microstructure.
\end{abstract}

Keywords: processing routes; chemical composition versus medical applications; hydrogels. (C) 2018 ACG Publications. All rights reserved.

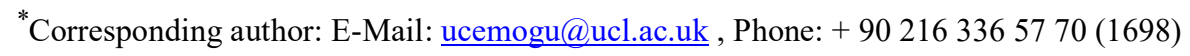

The article was published by ACG Publications 


\section{Introduction}

Hydrogels are polymers of soft or wet structures that are arranged in three-dimensional hydrophilic polymeric matrices, films or microspheres that can hold large amount of water or other biological fluids, without being dissolved due to their hydrophobic cross-linked structures ${ }^{1,2,3}$. This in turn causes the hydrogels to be considered for various drug delivery methods. As hydrogels exhibit thermodynamic compatibility with water, they swell in aqueous media. In addition to the ability of synthesizing them from a large variety of synthetic polymers, they provide a wide range of application possibilities and choice of substances that could be used for their production and being loaded with a large number of different substances and molecules. Although these materials were initially obtained from natural resources, they were later synthesized as synthetic polymers and had a higher water absorption capacity, longer service life and larger spectra of chemical resources available ${ }^{3}$. Hydrogels are used in tissue engineering and tailored drug delivery mechanisms ${ }^{4,5}$. In soft tissue engineering, particularly, collagen, chitosan and bacterial cellulose are used in obtaining hydrogels that are able to speed up the healing process. Moreover, if proper biologically active agents are used, additional properties can be assured such as antimicrobial, antitumor and analgesic activities. As proposed by Murugan and Ramakrishna ${ }^{6}$, four generations of bone grafting materials are known, i.e. metals and alloys $\left(1^{\text {st }}\right.$ generation $)$, polymers and ceramics $\left(2^{\text {nd }}\right.$ generation $)$, composite materials ( $3^{\text {rd }}$ generation $)$ and tissue engineered grafts (nanocomposite materials loaded with cells, growth factors, etc.) ( $4^{\text {th }}$ generation). Collagen, chitosan and alginate, along with calcium phosphates (and especially hydroxyapatite) are suitable for bone grafting. Their composition and morphology are tailored to meet the biomechanical requirements ${ }^{7-13}$.

\section{Hydrogel types}

\subsection{PLGA-based hydrogels}

PLGA - based hydrogels are made of hydrophobic polymeric networks, which could be constructed with poly(lactic acid) - PLA or poly(lactide-co-glycolide) - PLGA. The advantage of using PLGA is that its hydrolysis causes the production of lactic and glycolic acids. These two acids are monomers that are endogenous and easily metabolised, thereby causing a minimal systemic toxicity. Yet, they have limited water absorption capabilities.

\subsection{Photopolymerized hydrogels}

Photopolymerization is a method, requiring different spectra of light to start the process of linear polymer cross linked structure polymerization. This method is proposed to be used specifically for the production of biomaterial-based polymer networks for specific biomedical applications and, particularly, in tissue engineering due to their ability to entrap a wide range of cells and substances.

\subsection{Nanomedicine - based hydrogels}

Lipid nanocapsules (LNC) are nanocarriers composed of an oily core of triglycerides surrounded by a surfactant shell ${ }^{2}$. They have been under extensive studies to be used in drug delivery applications. That is due to their long-term stability, biocompatibility, ability to encapsulate a large array of different drugs and easy and low cost preparation procedure. They can be administered in a variety of methods such as subcutaneous, intravenous and local delivery. A new method has been developed constituting LNG and $\mathrm{GemC}_{12}$. Even though this method is concerned with a hydrogel preparation, it has no polymeric constituents. The hydrogel structure is formed due to the location of the $\mathrm{GemC}_{12}$. As this method has no other synthetic polymer present other than the $\mathrm{GemC}_{12}$ at the LNG oil water interface, these hydrogels in turn reduce the risk of side effects. 


\subsection{Theranostic gelation hydrogels}

Theranostic hydrogels are a class of polymeric hydrogels that are tailored to clinical and biomedical applications. This can help in a few aspects, such as assessing the biodistribution noninvasively, targeting the drug accumulation, a higher level of control on the drug release and increase the effectiveness and the therapeutical effects of the drugs via targeted drug release as well as the ability to predict the therapeutical response. An example for theranostic hydrogel is the $\mathrm{pH} / \mathrm{temperature}$ sensitive magnetic nanohydrogel that contains an agent for MR and fluorescence imaging.

\subsection{Thermo-reversible gelation polymers}

Thermo-reversible Gelation Polymers (TGP) is another novel drug delivery system. They are able to make reversible hydrogen bonding with water at around body temperature. Although TPGs are in hydrogel form at body temperature, they become soluble at ambient temperature. They are mainly composed of polyethylene glycol (PEG) combined with a thermo responsive polymer and poly-Nisopropylacryl amide. They are biocompatible, non-cytotoxic and completely pathogen free ${ }^{14}$.

\subsection{Poly(acrylamide)and poly(acrylicacid)}

Hydrogels prepared from polyacrylamide (PAAm) and polyacrylic acid (PAAc) have physically crosslinked networks generated via their hydrophobic association. They show no self-healing behaviour but exhibit a high adhesive capability when in contact with one another. That property is attributed to the hydrogen bonding between the amide and carboxyl groups of the PAAm and PAAc, respectively ${ }^{5}$.

Table 1. Hydrogels and their applications.

\begin{tabular}{llr}
\hline Hydrogel & Medical Application & Reference \\
\hline PLGA & Drug delivery, Tissue engineering, cancer treatment and imaging. & {$[31-33,34-37]$} \\
Photo-polymerizable & Tissue regeneration for bone, cartilage, and soft tissue, injectable & {$[38-41]$} \\
& controlled release devices for drug delivery. & {$[42-45]$} \\
LNC & Drug delivery, Chemotherapeutical agent delivery (glioblastoma), & {$[46,47]$} \\
Theranostic & Drug delivery (cancer treatment), diagnostics, & {$[37]$} \\
TGP & Food additives, pharmaceutical ingredients, agricultural products & {$[48]$} \\
PAAm PAAc & Drug delivery, prodrugs, cancer therapy. & {$[16-21]$} \\
Collagen & Tissue engineering, Drug delivery, cosmetic, pharmaceutic and food & {$[30]$} \\
& industry, etc. & \\
Chitosan & Tissue engineering, drug delivery systems; wound dressing, & \\
& antimicrobial agent &
\end{tabular}

\subsection{Collagen}

Collagen is a class of natural polymer/protein structure which is extensively used in tissue engineering of soft and hard tissues ${ }^{15-19}$, being one of the most important components of these tissues. Collagen and its derivative, gelatine, is also intensively used in pharmaceutical, cosmetic and food industries ${ }^{20}$. The chemical structure allows it to be used as a platform for loading and delivering biological active agents. It can be applied with or without other organic and inorganic components along with an important number of biologically active agents capable of assuring specific functionalities (analgesic, anti-inflammatory, anti-tumoral and anti-infective properties ${ }^{11,21-26}$ ). All these properties are 
coupled with its native properties such as good haemo- and tissue-compatibilities and ability to absorb high amount of water ${ }^{27-29}$.

\subsection{Chitin}

Chitin and its deacetylated form chitosan are extensively used in biomedical applications because of their remarkable biocompatibility, high water uptake assuring healing conditions for the injuries and native antimicrobial activity due to their polycationic structure ${ }^{30,31}$. All types of hydrogels are summarized in Table 1 together with references corresponding to their application fields.

\section{Methods of hydrogel preparation}

Several methods are used in order to prepare hydrogels, the most important one of which is given below.

\subsection{Conventional polymerization and crosslinking}

Polymerization and covalently crosslinking are conventional methods for hydrogel preparation, which can be applied for the synthesis of large range of materials. These methods can be used to create specific hydrogels by combining different monomers or polymers to obtain hydrogels, having specific physio-, mechanic- and chemical properties ${ }^{6,49,50}$. Bio-hydrogels or their composite forms can be obtained using proper multifunctional cross-linking agents (Figure 1). The cross-linking reactions can be initiated using thermal, redox or photo (UV-VIS) initiators. Ionizing radiation techniques such as gamma and electron-beam are also used because of their remarkable practical advantages. The presence of solvent in the polymerization process provides a considerable advantage in terms of heat transfer since the polymerization reactions are highly exothermic. There are mainly four types of radical polymerization used in both industry and laboratory; bulk, solution, suspension and emulsion polymerizations, each having own practical advantages and disadvantages ${ }^{7}$. In the preparation of hydrogels aiming at medical applications, rather than synthetic monomers, the use of naturally formed polymers, such as collagens and alginates or variety of fermentation products such as hyaluronic acid and poly(hydroxy alkanoates), is especially desired to avoid possible local inflammations. Collagen based hydrogels are widely used for medical applications. It is extracted form bovine calf and processed to obtain hydrogels with favorable characteristics for tissue regeneration and drug delivery. Tannins and glutaraldehyde are especially used as crosslinking agents. Their concentrations assess some characteristics properties such as elasticity, swelling, water absorption, chemical stability and biocompatibility.
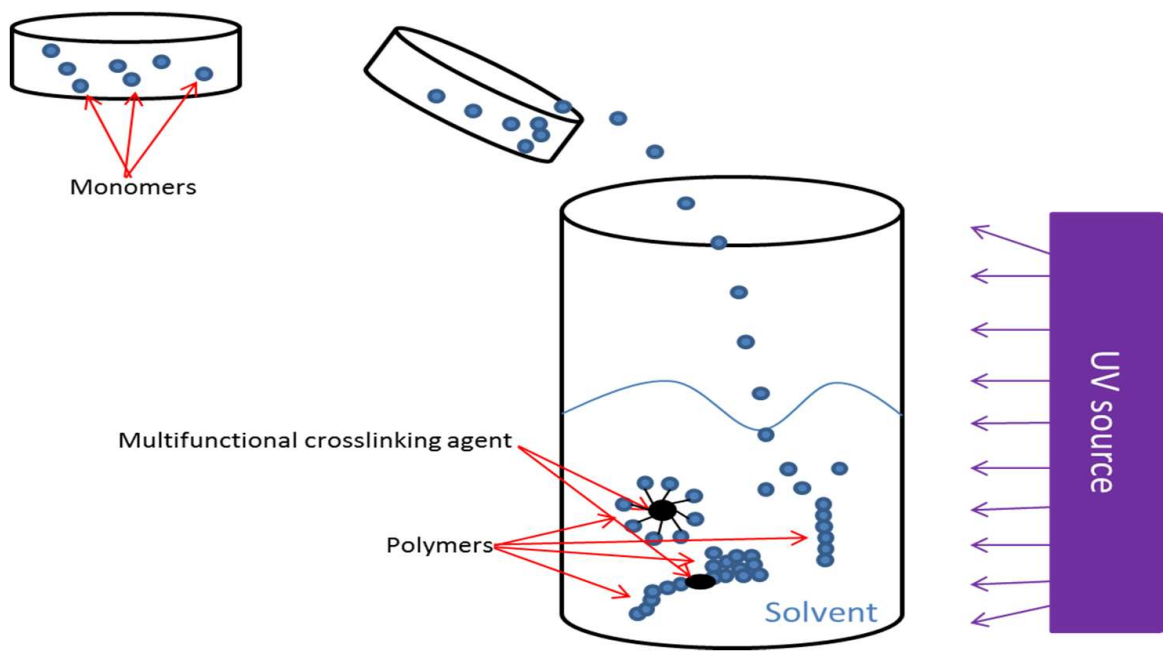

Figure 1. Conventional polymerization method. 


\subsection{Electro-hydrodynamic atomization}

Electro-hydrodynamic atomization (EHDA), also known as electro-spraying technique, is a well-established technique and used for the generation of very fine uniform droplets under the influence of an electrical force. It is applied for the production and process of micro and nanoparticulate materials. As can be seen in (Figure 2a), this device consists mainly of five parts: a syringe pump, a syringe holding the material to be used, a needle/injector used as a nozzle, a power source to provide an electrical force and a grounded collector bed. The mechanism of EHDA device is the bulk fluid disburses into fine droplets, under the influence of an electrical field that appears to be coming out in a mist form (Figure 2b). Here, an important point is the fluid surface tension, which, if it exceeds the certain amount of electrical stress, fluid is atomized upon leaving the nozzle. Additionally, the physiochemical properties of the solvent will determine the size and surface roughness of the resultant particles, i.e. the vapor pressure and therefore the boiling point ${ }^{34}$.

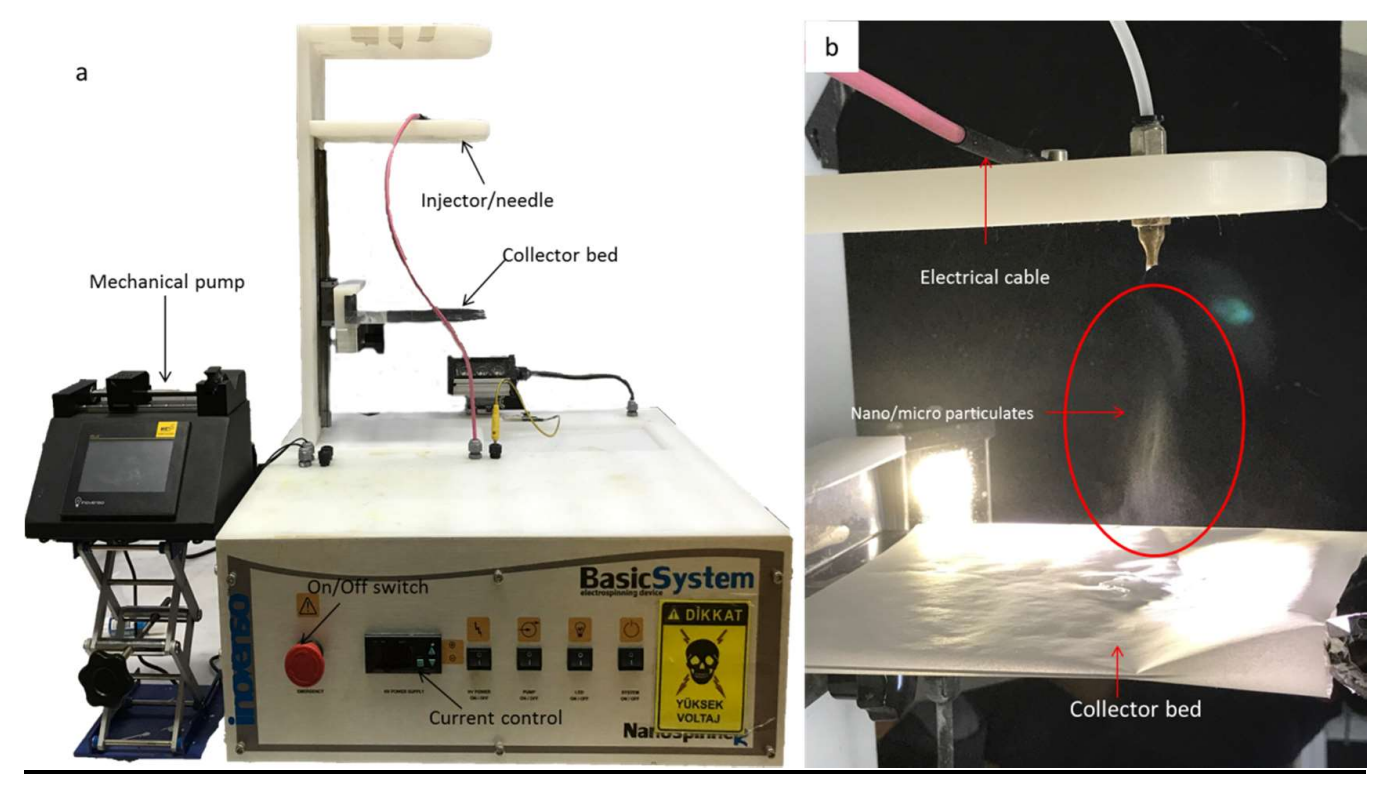

Figure 1. (a) EHDA device (b) particles produced during EHDA process.

Electrohydrodynamic method is a powerful technique to provide nano- and microparticles to allow an easy size control, high recovery and mild processing conditions by controlling some parameters such as conductivity of spraying liquids, flow rate, potential and distance between the needle and collector, etc. ${ }^{50-51}$. Starting from PCL, PEG and chitosan, by electrospinning at $12 \mathrm{kV}$, efficient nanoencapsulation of albumin was obtained. The characteristics of the obtained micro and nanoparticles, according to the processing parameters, are presented in Table 2 . 
Table 2. Characteristics of the nano- and microparticles obtained by EHDA

\begin{tabular}{|c|c|c|c|c|c|}
\hline Polymer & $\begin{array}{c}\text { Dispersant } \\
\text { wt } \%\end{array}$ & $\begin{array}{c}\text { Flow rate } \\
\mathrm{ml} / \mathrm{h}\end{array}$ & $\begin{array}{c}\text { Voltage } \\
\mathbf{k V}\end{array}$ & $\begin{array}{c}\text { Distance } \\
\text { cm }\end{array}$ & $\begin{array}{c}\text { Diameter } \\
\qquad \mu \mathrm{m}\end{array}$ \\
\hline Chitosan & $\begin{array}{c}\text { TPP, } \\
0.5 \mathrm{wt} \% \text { aq } \\
\text { TPP } \\
0.02 \mathrm{wt} \% \text { aq } \\
\text { HPC } \\
1 \mathrm{wt} \% \text { methanol }\end{array}$ & $0.2-1.0$ & $4-16$ & $0.5-7$ & $\begin{array}{l}2.5-19.4 \\
3.1-18.4\end{array}$ \\
\hline $\mathrm{PCL}^{1}$ & $\operatorname{PBS}(\mathrm{pH}=7.4)$ & $0.1-0.4$ & 10 & 3 & $22.5-11.4$ \\
\hline $\begin{array}{c}\mathrm{PEG} / \mathrm{PCL}^{2} \\
\text { in / out }\end{array}$ & $\begin{array}{c}\text { SDS } \\
1 \mathrm{mM} \mathrm{aq} \\
\end{array}$ & $\begin{array}{c}\text { in: } 0.5-3 \\
\text { out: } 0.5-2 \\
\end{array}$ & 10 & 3 & $0.12-0.70$ \\
\hline \multicolumn{6}{|c|}{ 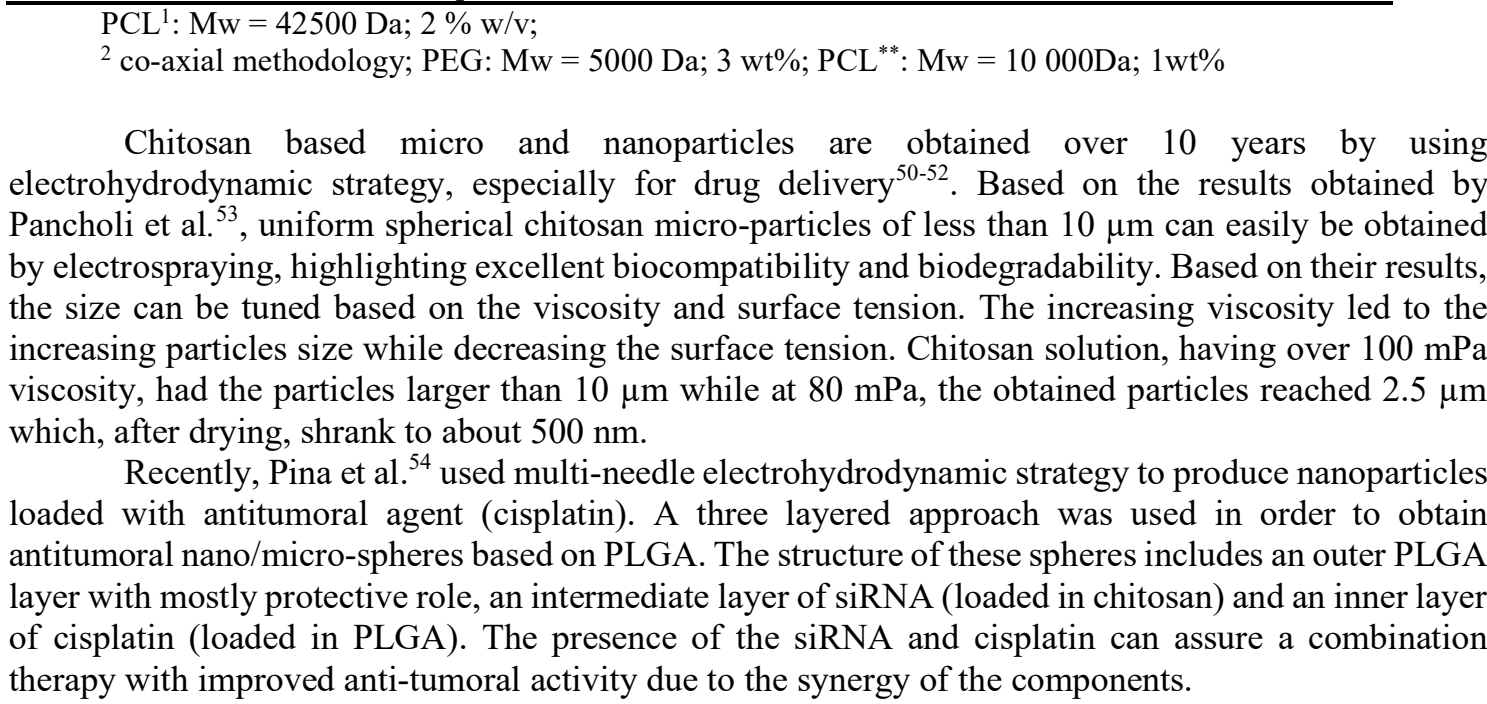 } \\
\hline
\end{tabular}

\subsection{Electrospinning}

Electrospinning is a method similar to EHDA with the only difference in the microstructure of the resultant scaffold. The design of the electrospinner is similar to that of the EHDA device (Figure 5). When EHDA is used, the product comes out as spherical balls or clusters and with electrospinning they come out as fibers, followed by their interconnection to form a 2D network (the thickness is usually much lower comparing with the other dimensions $)^{55-56}$. The electrospinned fibers have several desirable characteristics such as a large specific surface area, high flexibility that can be utilized in surface functionality, superior mechanical properties, adjustable porosity, tunable water uptake and air permeability as well as the ability to produce fibers of different shapes and sizes. On the other hand, electrospinning has a few disadvantages such as the hardship of production on a large scale that incorporates safety and toxicity of the solvent used and the high voltage used in the electrospinning process $^{55}$.

Chitosan is intensively used to obtain scaffolds based on micro and nano-fibrous structures. 3D printing as well as electrospinning, due the fluidity of the acidic chitosan solution, is hard to be used without a post-curing process (crosslinking). This process is devoted to reduce the fluidity and to stabilize the resulting strands (3D printing) / fibers (electrospinning). Genipin, along with the other agents, can be used for crosslinking the chitosan based fibers and the obtained scaffolds can be used even in tissue engineering because of the low toxicity and high ability to assure the adhesion and maturation of the osteoblast cells $\mathrm{s}^{57}$. Asran et al. $^{58}$, starting form polyvinyl alcohol, collagen and hydroxyapatite, obtained nanofibrous biocomposite scaffolds mimicking some of the key features of natural bone at nanoscale level. Experimental models of $7 \mathrm{~cm} \times 11 \mathrm{~cm}$ nanofibrous scaffolds were 
obtained with controlled/adjustable fiber diameter, pore size and porosity (Table 3). In the case of $\mathrm{PVA} / \mathrm{COL} / \mathrm{nHA}$, the average pore size is $650 \mu \mathrm{m}$, the porosity reaches $49.5 \%$ while the mechanical properties are suitable for the tissue engineering of spongious bones.

Table 3. Morphological and mechanical characteristics of the nanofibrous scaffolds.

\begin{tabular}{|c|c|c|}
\hline \multirow[t]{2}{*}{$\underline{\text { Sample }}$} & Diameter of fibers & Mechanical properties / Elastic modulus \\
\hline & $\lfloor\mathrm{nm}]$ & {$[\mathrm{MPa}] /$ [MPa] } \\
\hline$\underline{\mathrm{PVA}}$ & $\underline{160}$ & $0.22 \pm 0.09 / 2.67 \pm 0.78$ \\
\hline$\underline{\mathrm{PVA} / \mathrm{nHA}}$ & $\underline{176}$ & $\underline{\mathrm{NA}}$ \\
\hline$\underline{\mathrm{PVA} / \mathrm{COL}}$ & $\underline{245}$ & $\underline{0.62} \pm \underline{0.13 / 4.97} \pm \underline{2.41}$ \\
\hline \multirow[t]{2}{*}{$\underline{\mathrm{PVA} / \mathrm{COL} / \mathrm{nHA}}$} & $\underline{320}$ & $5 \%$ nHA: $1.03 \pm 0.17 / 11.10 \pm 3.38$ \\
\hline & & $10 \%$ nHA: $0.17 \pm 0.05 / 0.10 \pm 0.94$ \\
\hline
\end{tabular}

Electrospinning was also used for manufacturing $\mathrm{pH}$-responsive composite hydrogels based on poly[styrene-co-(maleic sodium anhydride)] (SMA) and cellulose with nanofibrous structure ${ }^{58}$. Three compositions were obtained starting from SMA and cellulose acetate by varying their ratio from 10:90 to 20:80 and 40:60. In all cases, their solubilisation was conducted in N,N-dimethylacetamide/acetone $1: 2(\mathrm{v} / \mathrm{v})$ and electrospinned at a feeding rate of $0.6 \mathrm{ml} / \mathrm{h}$ at $16 \mathrm{kV}$, while the tip-to-collector distance was $16 \mathrm{~cm}$ followed by drying at $80{ }^{\circ} \mathrm{C}$ and crosslinking thermally at $145{ }^{\circ} \mathrm{C}$ or chemically using diethylene glycol (3\% relative to SMA). The chemically crosslinked SMA/cellulose exhibits a $\mathrm{pH}-$ dependent swelling/de-swelling behaviours. At acidic $\mathrm{pH}$ (2.5-5.5), the swelling is of $\sim 1700-1900 \%$ and slightly increases to $2000 \%$ between 5.5 and 8.4. An important increase appears reaching up to $2700-2800 \%$ above $\mathrm{pH} 9$.

Electrospinning can also be used in a two-syringe configuration as presented by Ji et al. ${ }^{59}$. They used a thiolated derivative of hyaluronic acid and poly(ethylene glycol) diacrylate (PEGDA) as crosslinking agents. The hyaluronic acid derivative was dissolved in a $2.5 \%(\mathrm{w} / \mathrm{v})$ PEO solution (in Dulbecco's modified eagle's medium - DMEM). PEO was used to act as a viscosity controlling agent which was later removed by washing with water and filled in one syringe while the second syringe contains $9 \%(\mathrm{w} / \mathrm{v})$ PEGDA solution in PBS $(\mathrm{pH}=7.4)$. The electrospinning process was performed using a T-shape three-way steel adapter. The spinning process was assured by a potential of $18 \mathrm{kV}$, and the needle was placed horizontally at $10 \mathrm{~cm}$ distance from the collector. The feeding rate was set at 1.2 for $\mathrm{HA} / \mathrm{PEO}$ blend and $0.3 \mathrm{~mL} / \mathrm{h}$ for the PEGDA crosslinking agent. The mean diameter of the fibers is 110 $\pm 28 \mathrm{~nm}$ (after removal of PEO, the fibers were not degraded even after prolonged washing). This scaffold, based on the biological assays and the swelling behaviour, seems to be adequate for tissue engineering of the soft-tissue. Most probably, these materials can also be loaded with biologically active agents able to induce faster healing. Moreover, they show analgesic and antibacterial properties. Drug delivery wound dressings obtained by electrospinning are increasingly exploited in medical applications ${ }^{60-62}$. Antibiotic (gentamicin sulfate and hydrophobic ciprofloxacin) loaded gelatine-based wound dressings were used for dermal regeneration of infected deep burns ${ }^{60}$. The use of the two antibiotics is justified based on their different release performance; gentamicin being released within 6 days while ciprofloxacin in over 3 weeks, after which the re-epithelization was practically complete.

Recently, Park et al. ${ }^{63}$ manufactured poly(caprolactone)/calcium carbonate electrospinned network coated with chitosan to regulate the haemostatic properties and, based on the in vivo assays, it was found that these materials can be used when rapid blood coagulation is required.

\section{4. $3 D$ printing}

3D printing is a method for synthesizing three-dimensional objects of various shapes and sizes from a digitalised model. 3D printing has the potential to fix or replace different tissues or organs. In contrast to other methods of scaffold fabrication that create a random scaffold with no apparent pattern, 3D printing allows a full control over the design of the scaffold in regard to shape, size and porosity. 3D 
printers consist mainly of a material pump, thermal unit (heating or cooling ability), an injector/needle, movable head and a collector/print base (Figure 3). 3D printing implements an additive manufacturing (AM) that applies one consecutive layer over the other to reach the desired shape ${ }^{64}$. We can see the schematic representation of 3D liquid bio-printing in Figure 4. There are a lot of different additive processes including:
a. Selective Laser Sintering (SLS)
b. Stereo-Lithography (SLA)
c. Fuse Deposition Modeling (FDM)
d. Direct Metal Laser Sintering (DMLS)

Each of the process above differs in the materials they use as well as the type of the printing method. Different tissues and organs could be printed with the help of 3D printers such as: cartilages ${ }^{65}$, bones ${ }^{66}$, vessels $^{67,68}$, nerves ${ }^{69}$, bladders ${ }^{70}$ and many more. Additionally, for medical purposes, the created scaffolds were made of both natural and synthetic polymers. Natural polymers, such as collagen ${ }^{71}$, chondroitin sulphate ${ }^{72}$, chitin ${ }^{73}$ and chitosan ${ }^{74}$, are mainly used for tissue engineering and organ regeneration to the facilitate cell attachment and maintenance of differentiation. On the other hand, synthetic polymers are used in a large variety of applications as they are able to provide versatility regarding the control of their physiochemical properties and make different scaffolds ${ }^{75-77}$. Some examples of different synthetic polymers include poly( $\varepsilon$-caprolactone) (PLC), poly(lactic acid)(PLA), poly(glycolic acid) (PGA), poly(lactic-co-glycolic acid) (PLGA) and poly(ethylene glycol)(PEG) ${ }^{64}$. Nowadays, a wide variety of hydrogels are studied for tissue engineering, including graphene oxides based hydrogels such as gelatine - poly(ethylene glycol)diacrylate - graphene oxide ${ }^{78}$ for cartilage reconstruction and poly(N-acryloyl glycinamide) - nanoclay. The latter, due to the $\mathrm{Mg}^{2+}$ and $\mathrm{Si}^{4+}$ release, exhibits very good osteogenic differentiation of primary rat osteoblasts, making them recommended for bone grafting. Drug loaded hydrogels are also of great interest in the field of cancer treatment, especially to avoid recurrences ${ }^{79,80}$.

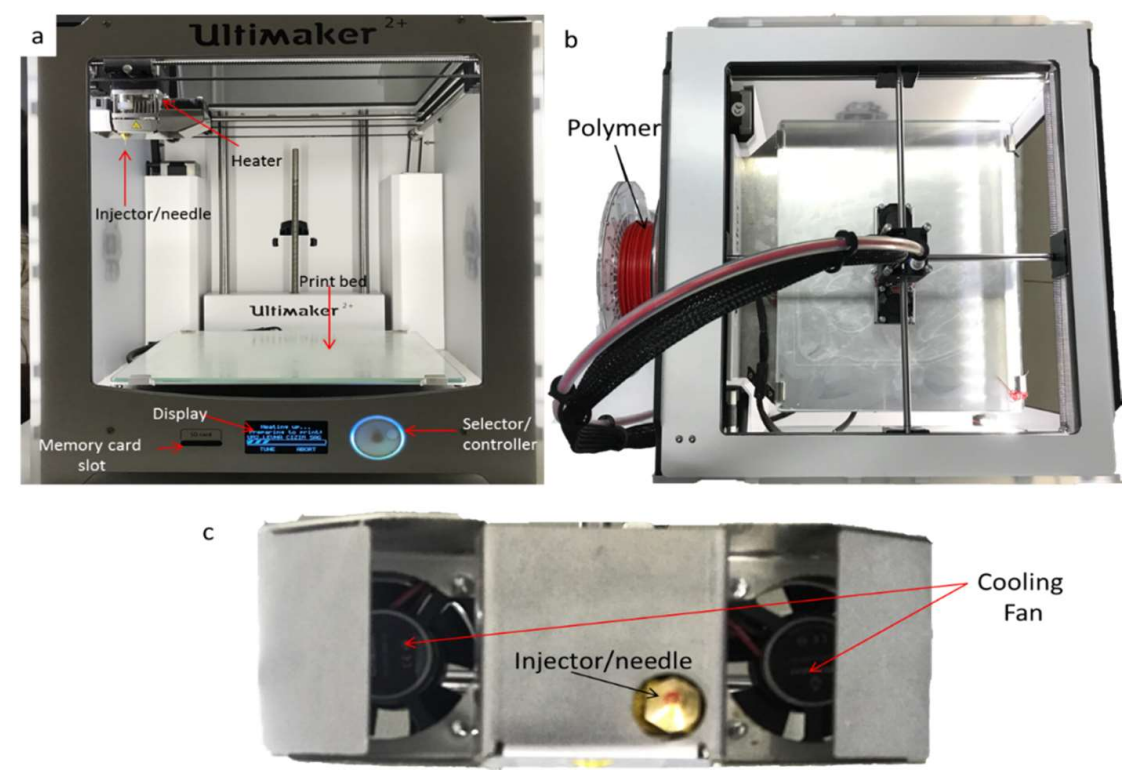

Figure 3. 3D printer (a) front view (b) top view (c) the moving injector. 


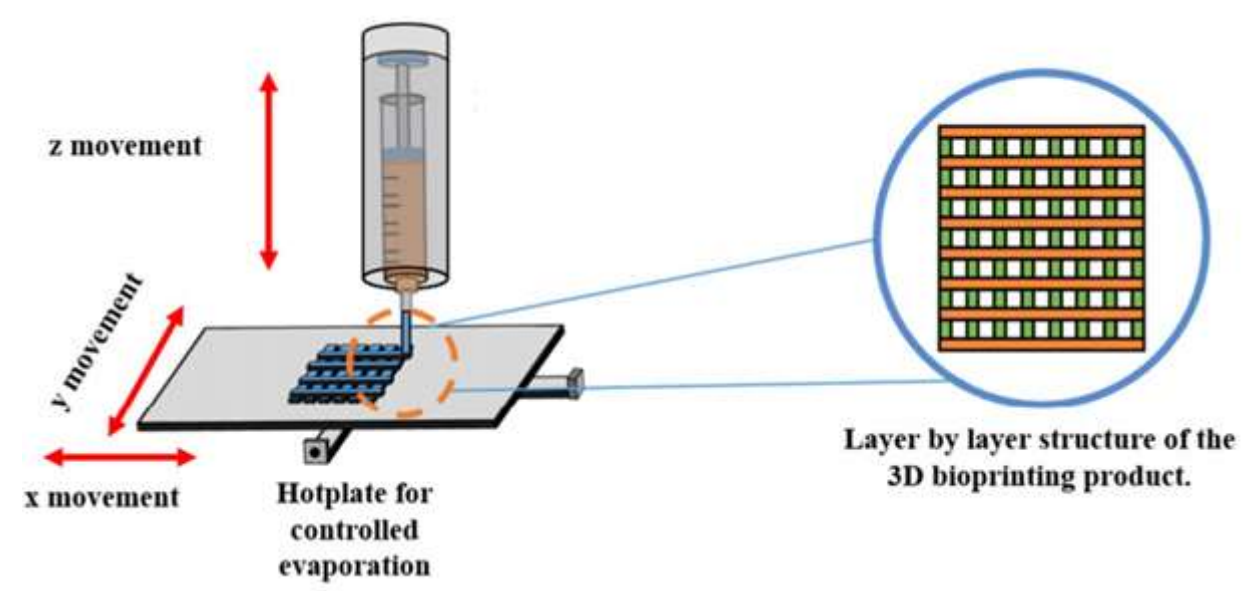

Figure 4. Schematic diagram of the 3D liquid bio printing.

Development of bone grafts is of great importance as the need for bone grafts is high. In this context, many research groups have been trying to develop bone grafting materials to tailor their morphology to obtain the desired properties. Alginate - polyvinyl alcohol - hydroxyapatite can be used to develop bone grafts ${ }^{81}$ seeded with cells. For this reason, the rheological properties are very important since high pressure can destroy the mouse calvaria 3T3-E1 cells. Six different formulations were tested containing different amount of alginate (Alg), phosphate, calcium, hydroxyapatite (HA) and sodium chloride (Table 4). Based on the video images, the 3D printed samples, obtained from the formulations containing $2.5 \%$ alginate, seems to lead to a more stable $3 \mathrm{D}$ structure with a good printing. The $5^{\text {th }}$ formulation led to the highest compressive modulus during the degradation study while the diameter change is minimal.

Table 4. Composition of the hydrogel.

\begin{tabular}{cccccc}
\hline Number & \multicolumn{5}{c}{ Content of \% } \\
\cline { 2 - 6 } & Alg & $\mathbf{N a H}_{2} \mathbf{P O}_{4}$ & $\mathrm{CaSO}_{4}$ & $\mathbf{H A}$ & NaCI \\
1 & 1.5 & 0.12 & 0.40 & 0 & - \\
2 & 2.0 & 0.12 & 0.40 & 0 & - \\
3 & 2.0 & 0.12 & 0.40 & 2.5 & - \\
4 & 2.0 & 0.12 & 0.20 & 2.5 & - \\
5 & 2.5 & 0.15 & 0.20 & 2.5 & - \\
6 & 2.5 & 0.15 & 0.20 & 2.5 & 0.72 \\
7 & 2.5 & 0.15 & 0.20 & 0 & - \\
\hline
\end{tabular}

Nanocellulose-alginate hydrogels were manufactured by 3D printing in order to provide biomedical devices, wearable sensors and drug delivery systems ${ }^{82}$. The ternary systems, based on nanocellulose-alginate and glycerin, provide good printability, as the obtained materials presenting mmlarge pores, which are extremely important as they can assure low irritation and pain induced by the compressive forces developed during healing. Moreover, the avidin-functionalized nanocellulosealginate hydrogels can provide high immobilization ability via biotin-avidin interactions. Similarly, growth factors and antimicrobial agents (such as antibiotics) can be attached to develop drug delivery systems.

3D printed hydrogels, based on thiol-ene crosslinked polyglycidols and hyaluronic acid, containing amino and carboxy functionalized mesoporous silica nanoparticles, were obtained by 3D printing $^{83}$. The printability of the hydrogels, loaded with two types of mesoporous silica nanoparticles 
(amino and carboxy functionalized MSNs), was practically same but, the migration of the positively $\left(\mathrm{MSN}-\mathrm{NH}_{2}\right)$ or negatively charged MSN $(\mathrm{MSN}-\mathrm{COOH})$ was very different when immersed in PBS. If the two strands, one containing $\mathrm{MSN}_{-} \mathrm{NH}_{2}$ and the other containing $\mathrm{MSN}-\mathrm{COOH}$, are in contact, even after 1 day, the amino-functionalized MSN migrates but the carboxy-functionalized MSN does not migrate, regardless 1 day or 6 weeks of immersion in PBS. If the two strands are not in contact, after one day, no significant migration can be observed. On the other hand, after 6 weeks, the migration of the amino-functionalized MSN is important. The migration of the MSNs was monitored by using small amino and carboxy-functionalized MSNs, which were mixed with the corresponding hydrogels containing amino and carboxy-functionalized MSNs. Based on this study, the possibility of using printed scaffolds, loaded with positively and negatively charged drugs, can be used as sequential drug delivery systems.

Alginate/gelatine based hydrogels were also used in printing heterogeneous aortic valves with anatomical architecture by direct incorporation of two types of cells, meaning smooth muscle cells (SMC) for the root region and aortic valve leaflet interstitial cells (VIC) for the leaflet region ${ }^{84}$. A cellular 3D printed hydrogels exhibit lower mechanical properties comparing with the graft loaded with cells. The direct printing of the hydrogels encapsulating cells can be exploited as the viability is high enough, $81.4 \pm 3.4 \%$ for SMC and $83.2 \pm 4.0 \%$ for VIC. On the other hand, if these artificial valves are maintained in adequate culture media, they can survive for at least 7 days.

\subsection{Microfluidics}

Microfluidics is a system that allows precise control and manipulation of very small volumes ranging from $\mathrm{nL}$ to $\mathrm{pL}$ in a reproducible fashion. Microfluidics platforms are generally made of a pump or an actuator, a valve, a drug reservoir and a membrane to control the drug release rate (Figure 5). These systems are used in a large variety of applications ranging from developing biomaterials that allow a controlled release of drugs to discover proteins or antibodies that ensure the specificity of the action $^{85}$. These systems can be used in active and local drug delivery with planned release of drug in certain amount of time. Also it can be used for the administration of drugs that might carry the risk of cytotoxicity upon systematic administration. Instead of other drug administration methods that might incorporate a painful and hazardous needle injections this method is much more easy ${ }^{86}$. The particles in microfluidic systems are generally created via self-assembly, where two or more streams of different reagents are interfaced and the carriers are formed at the interface layer. The self-assembly is generally achieved via hydrodynamic flow focusing (HFF) or active or passive mixing. The size of the carriers is controlled by mixing, rated between the different streams ${ }^{87}$, thereby creating quite advanced and complex drug carriers. In addition to that, microfluidic systems could be used for direct delivery of active molecules ${ }^{88}$. Using such a method increases the specificity of the drug delivery and ensures the drug reaching the target site, thereby decreasing the side-effects of the drug, caused by the interaction of the drug with other organs and tissues. Microfluidics has the ability to ensure a controlled convective drug delivery method, unlike the other methods that provide drug delivery via diffusive forces both in continuous and pulsatile manner. The platform reservoir could be refillable or disposable. The main aim of the system is controlled release of the drug from the platform, which could be a great challenge in microfluidic platforms. This is achieved via the pump being controlled and moved mechanically or by pressurising it to force the drug out ${ }^{88}$ (Figure 6). 


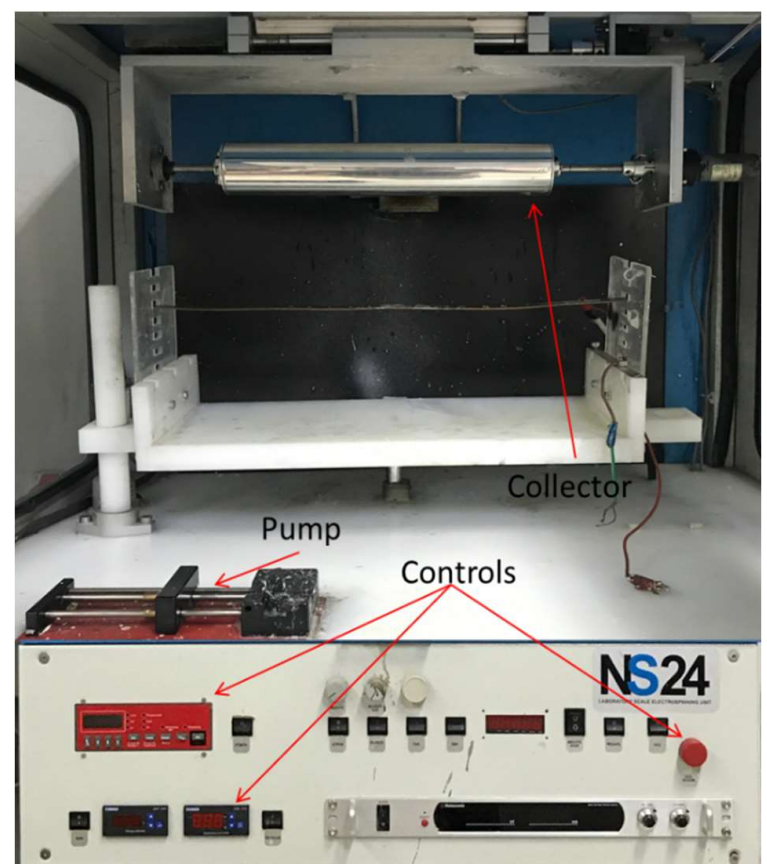

Figure 5. Electrospinning device.

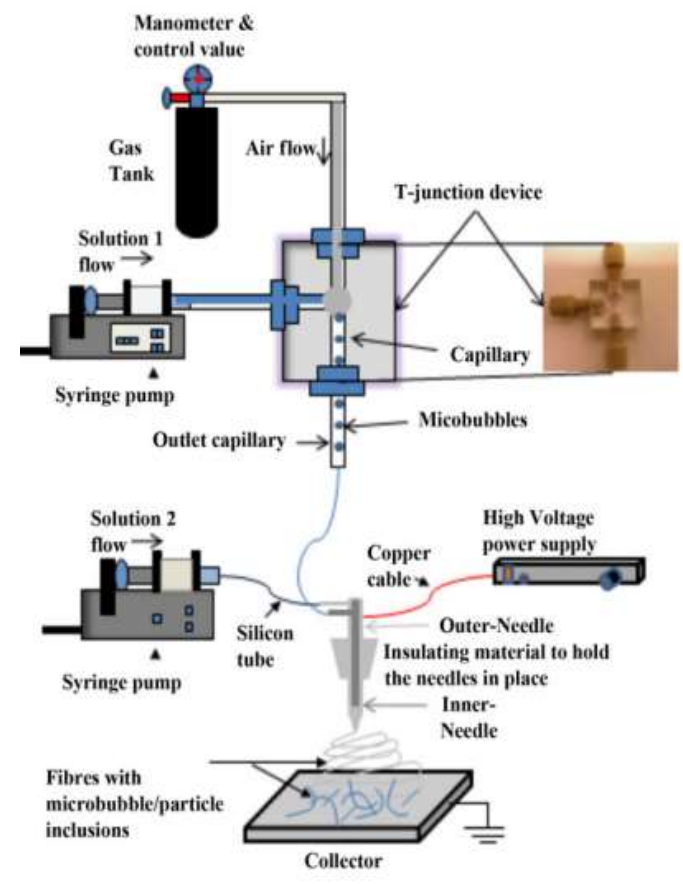

Figure 6. System design of microfluidics.

Microfluidic systems can be used in obtaining monodisperse hydrogel microsphere incorporating cells or biologically active agents. Alginate is extensively used in microfluidic approaches because of its fast and easy ionotropic gelation. The spherical alginate microspheres have found applicability in drug delivery, bio-sensing, microelectronics, bioanalysis cell delivery, etc. ${ }^{90}$. The size of the microcapsules can be tailored to accommodate fine nanoparticles, proteins as well as entire cells 
or several cells, maintaining the cellular viability ${ }^{90-92}$. Moreover, these microcapsules are stable enough, both in vitro and in vivo ${ }^{93}$. Thus, they are suitable for a wide range of applications.

The presented methods were used in developing new or improved hydrogels for medical and nonmedical applications. Some of the most important methods applied for the processing of the biomedical-grade polymers and composites are presented in Table 5.

Table 5. Applicable materials for each device.

\begin{tabular}{|c|c|c|}
\hline Method & Applicable Hydrogels & References \\
\hline$\overline{\text { EHDA }}$ & $\begin{array}{l}\text { chitosan, polycaprolactone (PCL), and poly(ethylene glycol) (PEG) } \\
\text { were processed by EHDA in order to obtain biodegradable polymeric } \\
\text { particles }\end{array}$ & $\begin{array}{l}{[94-96]} \\
{[25-29]}\end{array}$ \\
\hline 3D printing & $\begin{array}{l}\text { methacrylated chondroitin sulfate (CSMA), thermo-sensitive poly } \\
\text { (N-(2hydroxypropyl) methacrylamide-mono/dilactate)-polyethylene } \\
\text { glycol triblock copolymer (M15P10), conductive graphene doped } \\
\text { polylactic acid (G-PLA), pure PLA, stainless steel, ceramic beads, } \\
\text { inconel alloy, iron, ABS, ASA, nylon 12, PC, PPSF/PPSU, PEI or } \\
\text { ULTEM, PLA, TPU, titanium, aluminium, cobalt-chrome, Nickel } \\
\text { based alloys, DC (100, 500) DL (350, 360), AB 001, GM 08, DM } \\
\text { (210, 220), Rigid Polyurethane (RPU), Flexible Polyurethane (FPU), } \\
\text { Elastomeric Polyurethane (EPU), CE (Cyanate Ester) }\end{array}$ & [97-99] \\
\hline Microfluidics & $\begin{array}{l}\mathrm{N} \text {-alkylacrylamides, vinyl ether, alkylene oxide, -OH, -NH2, - } \\
\mathrm{CONH},-\mathrm{CONH}_{2}, \mathrm{COOH},-\mathrm{HSO}_{3} \text {, conductive polymer, } \\
\text { poly(thiophene)s, poly(p-phenylene sulfide), poly(pyrrole)s, } \\
\text { polyanilines, poly(acetylene)s; bismethacrylate-co-methacrylic acid } \\
\text { sodium salt, charged colour pigments, azobenzene, spiropyran, } \\
\text { triphenylmethane, cholesteric liquid crystal, carboxylic, } \\
\text { poly(methacrylic acid), poly(methacrylic acid-g-ethylene glycol); } \\
\text { amino groups, poly(N,N-dimethyl aminoethyl methacrylate); } \\
\text { sulfonic acid, poly(n-(morpholino) ethylmethacrylate)-b-poly (4-(2- } \\
\text { sulfoethyl)-1-(4-vinylbenzyl)pyridinium potaine), } \\
\text { (ferrocenylsilane), poly (lactic/ glycolic) acid, poly (methyl } \\
\text { methacrylate), polystyrene. Iron (III) oxide nanoparticles, cobalt } \\
\left.\text { ferrite (CoFe } \mathrm{O}_{4}\right) \text {, nickel ferrite, Poly(N-isopropylacrylamide) based } \\
\text { polymer nanogels, silver nanoparticles, titanium dioxide } \\
\text { nanoparticles, carbon black (paracrystalline carbon), conductive } \\
\text { nanoparticles, gold nanoparticles; Iron (II, III) oxide nanoparticles }\end{array}$ & [100-129] \\
\hline Electrospinning & $\begin{array}{l}\text { Starch, polymers (organic/inorganic), metals, metal oxides, } \\
\text { ceramics, sulfates. }\end{array}$ & {$[130,131]$} \\
\hline $\begin{array}{l}\text { Polymerization, } \\
\text { polycondensation } \\
\text { and crosslinking }\end{array}$ & $\begin{array}{l}\text { Acrylamide, acrylic acid, etc. } \\
\text { ethylene glycol, } \\
\text { collagen, alginate, chitosan, ... }\end{array}$ & [38] \\
\hline
\end{tabular}




\section{Conclusions}

Hydrogels are a versatile class of materials with various medical and nonmedical applications. Due to the presence of large volume of water, they are extremely well tolerated by human organism and consequently many applications of hydrogels are known, from soft to hard-tissue engineering, form regenerative to curative purposes. Hydrogels can be obtained starting from natural (collagen, chitosan, alginate, cellulose, etc.) or synthetic polymers (polylactic acid, poly(acrylic acid); poly(methyl methacrylate); poly(ethylene glycol), polycaprolactone, etc.). Moreover, ternary components can also be incorporated from cells and biological active agents to ceramic powders, graphene oxides and metallic nanoparticles. Besides the composition, the microstructure is an important issue, which must be considered when designing materials for tissue engineering. If only the classification of the materials is considered for bone grafting ${ }^{7}$, the tendency of the last decades seems to be oriented to material design, which globally includes both composition and morphology. Therefore, a wide range of processing technologies were designed and are extensively used in optimizing the properties of the materials. 3D printing is a versatile processing technique, which is especially beneficial as it allows tuning the microstructure of the materials. In bone grafting, main factor affecting the homeostasis is microstructure of the main elements $(\mathrm{Ca}, \mathrm{P})$. In addition to that, mechanical properties of spongious and compact bony tissue can affect it. Electrospinning, for instance, is essentially suitable in developing 2D structure, such as membranes for wound healing (with pure regenerative but also curative role), transdermal drug delivery, loco-regional delivery of drugs, etc.

\section{Acknowledgements}

The authors acknowledge the support of the UEFISCDI through the project PN-III-P2-2.1-PTE2016-0177 "Composite hydrogels based on inorganic nanoparticles and collagen with prolonged antimicrobial activity for the prevention of wound infections".

\section{ORCID}

Yunis Moukbil: 0000-0003-4880-1467

Faik Nuzhet Oktar: 0000-0003-2909-4787

Burak Ozbek: 0000-0003-2133-0001X

Denisa Ficai: 0000-0003-1243-6904

Anton Ficai: 0000-0002-1777-0525

Ecaterina Andronescu: 0000-0002-2226-5849

Mehmet Sayıp Eroglu: 0000-0003-0742-6162

Oguzhan Gunduz: 0000-0002-9427-7574

\section{References}

[1] Wu, S.; Dong,H.; Li,Q.; Wang, G.; Cao, X. High strength, biocompatible hydrogels with designable shapes and special hollow-formed character using chitosan and gelatin. Carbohydr. Polym. 2017, 168, 147-152.

[2] Bastiancich, C.; Danhier, P.; Preat, V.; Danhier, F. Anticancer drug-loaded hydrogels as drug delivery systems for the local treatment of glioblastoma. J. Control. Release. 2016, 243, $29-42$.

[3] Ahmed, E.M. Hydrogel: Preparation, characterization, and applications: A review. J. Adv. Res. 2015, 6, 105-121.

[4] Gi, M.S.; Cho, J.; Thambi, T.; Phan, V.H.G.; Kwon, I.; Lee, D.S. Bioengineered robust hybrid hydrogels enrich the stability and efficacy of biological drugs. J. Control. Release 2017, 267, 119-132.

[5] Itaya, T.; Udea, K.; Ochiai, H.; Imamura, A. Binding of hydrophobic counterions by polyelectrolyte and their hydrophobic association around polyion. Polym. J. 1993, 25(6), 545552 . 
[6] Murugan, R.; Ramakrishna, S. Development of nanocomposites for bone grafting. Compos. Sci. Techn. 2005, 65, 2385-2406.

[7] Ficai, M.; Andronescu, E.; Ficai, D.; Voicu, G.; Ficai, A. Synthesis and characterization of COLL-PVA/HA hybrid materials with stratified morphology. Colloids. Surf. B. Biointerfaces 2010, 81, 614-619.

[8] Nedelcu, I. A.; Ficai, A.; Ficai, D.; Voicu, G.; Albu, M. G.; Andronescu, E. Hybrid collagencarboxymethylcellulose/ hydroxyapatite composite materials for bone tissue regeneration. Sci. Bull. B Chem. Mater. Sci. UPB 2015, 77, 3-14.

[9] Ghica, M. V.; Ficai, A.; Marin, S.; Marin, M.; Ene, A. M.; Patrascu, J. M. Collagen/bioactive glass ceramic/doxycycline composites for bone defects. Rev. Rom. Mater. 2015, 45, 307-314.

[10] Ficai, A.; Albu, M. G.; Birsan, M.; Sonmez, M.; Ficai, D.; Trandafir, V.; Andronescu, E. Collagen hydrolysate based collagen/hydroxyapatite composite materials. J. Mol. Struct. 2013, 1037, 154-159.

[11] Ficai, M.; Andronescu, E.; Voicu, G.; Ficai, D.; Albu, M. G.; Ficai, A. Mollusc Shell/collagen composite as potential biomaterial for bone substitutes. Rev. Rom. Mater. 2010, 40, 359-364.

[12] Rusu, L. C.; Nedelcu, I. A.; Albu, M. G.; Sonmez, M.; Voicu, G.; Radulescu, M.; Ficai, D.; Ficai, A.; Negrutiu, M. L.; Sinescu, C. Tetracycline loaded collagen/hydroxyapatite composite materials for biomedical applications. J. Nanomater. 2015, Article ID 3619695 pages.

[13] Serafim, A.; Cecoltan, S.; Vasile, E.; Stancu, I. C. Polyacrylamide-gelatin hydrogels and mineralized hybrids. Influence of gelatin type. Sci. Bull. B. Chem. Mater. Sci. UPB 2015, 77, 189-200.

[14] Osman, A.; Oner, E. T.; Eroglu, M. S. Novel levan and pNIPA temperature sensitive hydrogels for 5-ASAcontrolled release. Carbohydr Poly. 2017, 165, 61-70.

[15] Rhee, S.; Puetzer, J. L.; Mason, BN.; Reinhart-King, C. A.; Bonassar, L. J. 3D Bioprinting of spatially heterogeneous collagen constructs for cartilage tissue engineering. Acs. Biomater. Sci. Eng. 2016, 2, 1800-1805.

[16] Zhang, Y. Y.; Mao, W. J.; Wang, J.; Li, Q. L.; Mei, M. L.; Chu, C. H.; Xia, R.; Zhang, Z. H. Antibacterial membrane with a bone-like structure for guided bone regeneration. J. Nanomater. 2015, Article ID 7845748 pages.

[17] Chae, J. J.; Mulreany, D. G.; Quo, Q. Y.; Lu, Q. Z.; Choi, J. S.; Strehin, L.; Espinoza, F. A.; Schein, O.; Trexler, M. M.; Bower, K. S.; Elisseeff, J. H. Application of a collagen-based membrane and chondroitin sulfate-based hydrogel adhesive for the potential repair of severe ocular surface injuries. Mil. Med. 2014, 179, 686-694.

[18] Yamaoka, H.; Tanaka, Y.; Nishizawa, S.; Asawa, Y.; Takato, T.; Hoshi K. The application of atelocollagen gel in combination with porous scaffolds for cartilage tissue engineering and its suitable conditions. J. Biomed. Mater. Res. A 2010, 93A, 123-132.

[19] Ferreira, A. M.; Gentile, P.; Chiono, V.; Ciardelli, G. Collagen for bone tissue regeneration. Acta. Biomater. 2012, 8, 3191-3200.

[20] Liu, D. S.; Nikoo, M.; Boran, G.; Zhou, P.; Regenstein, J. M. Collagen and gelatin. Ann. Rev. Food. Sci. T 2015, 6, 527-557.

[21] Kojima, C.; Suehiro, T.; Watanabe, K.; Ogawa, M.; Fukuhara, A.; Nishisaka, E.; Harada, A.; Kono, K.; Inui, T.; Magata, Y. Doxorubicin-conjugated dendrimer/collagen hybrid gels for metastasis-associated drug delivery systems. Acta Biomater. 2013, 9, 5673-5680.

[22] Sulea, D.; Ghica, M. V.; Micutz, M.; Albu, M. G.; Brazdaru, L.; Staicu, T.; Leca, M.; Popa, L. Characterization and in vitro release of chlorhexidine digluconate comprised in type I collagen hydrogels. Rev. Roum. Chim. 2010, 55, 543-551.

[23] Kaffashi, B.; Zandieh, A.; Khadiv-Parsi, P. Drug release study of systems containing the tragacanth and collagen composite: Release characterization and viscoelastic measurements. Macromol. Symp. 2006, 239, 120-129.

[24] Young, S.; Wong, M.; Tabata, Y.; Mikos, AG. Gelatin as a delivery vehicle for the controlled release of bioactive molecules. J. Control. Release. 2005, 109, 256-274.

[25] Solorio, L.; Zwolinski, C.; Lund, A. W.; Farrell, M. J.; Stegemann, J. P. Gelatin microspheres crosslinked with genipin for local delivery of growth factors. J. Tissue. Eng. Regen. Med. 2010, 4, 514-523.

[26] Albu, M. G.; Titorencu, I.; Ghica, M. V. Collagen-based drug delivery systems for tissue engineering. In biomaterials applications for nanomedicine, Rosario P, Ed; InTech, Rijeka, 2011.

[27] Mian, M.; Beghe, F.; Mian, E. Collagen as a pharmacological approach in wound-healing. Int. J. Tissue. React. 1992, 14, 1-9.

[28] Albu, M. G. Collagen gels and matrices for biomedical applications, Lambert Academic Publishing, Saarbrücken, 2011. 
[29] Sahin, Y. M.; Yetmez, M.; Oktar, F. N.; Gunduz, O.; Agathopoulos, S.; Andronescu, E.; Ficai, D.; Sonmez, M.; Ficai, A. Nanostructured biomaterials with antimicrobial properties. Curr. Med. Chem. 2014, 21, 3391-3404.

[30] Singh, A.; Sharma, P. K; Garg, V. K.; Garg, G. Hydrogels: A Review. Int. J. Pharm. Sci. Rev. Res. 2010, 4(2), 97-105.

[31] Bostan, M. S.; Senol, M.; Cig, T.; Peker, I.; Goren, A. C.; Ozturk, T.; Eroglu, M. S. Controlled release of 5-aminosalicylicacid from chitosan based $\mathrm{pH}$ and temperature sensitive hydrogels. Int. J. Biol. Macromol. 2013, 52, 177- 183.

[32] Saxena, A. K.; Synthetic biodegradable hydrogel (PleuraSeal) sealant for sealing of lung tissue after thoracoscopic resection. J. Thorac. Cardiovasc. Surg., 2010, 139(2), 496-497.

[33] Kashyap, N.; Kumar N.; Ravi Kumar, M. N. V. Hydrogels for pharmaceutical and biomedical applications Crit.Rev. Ther. Drug. Carrier. Syst. 2005, 22(2), 107-149.

[34] Xie, J.; Jiang, J.; Davoodi, Pooya.; Srinivasan, M. P.; Wang, C. Electrohydrodynamic atomization: A two-decade effort to produce and process micro-/nanoparticulate materials. Chem. Eng. Sci. 2015, 125, 32-57.

[35] Chung, T. W.; Chou, T. H.; Wu, K. Y. Gelatin/PLGA hydrogel films and their delivery of hydrophobic drugs. J. Taiwan. Inst. Chem. Eng. 2016, 60, 8-14.

[36] Naahidi, S.; Jafari, M.; Logan, M.; Wang, Y.; Yuan,Y.; Bae, H.; Dixon, B.; Chen, P. Biocompatibility of hydrogel-based scaffolds for tissue engineering applications. Biotechnol. Adv. 2017, 35(5), 530-544.

[37] Zhao, W.; Li, J.; Jin, K.; Liu, W.; Qiu, X.; Li, C. Fabrication of functional PLGA-based electrospun scaffolds and their applications in biomedical engineering. Mater. Sci. Eng. C Mater. Biol. Appl. 2015, 59, 1181-1194.

[38] Ullah, F.; Hafi Othman, M. B.; Javed, F.; Ahmad, Z.; Akil, H. Classification, rocessing and application of hydrogels: A Review. Mater. Sci. Eng. 2015, 57, 414-433.

[39] Hubbell, J. A. Synthetic biodegradable polymers for tissue engineering and drug delivery, Curr. Opin. Solid. State. Mater. Sci. 1998, 3, 246-251.

[40] Balakrishnan, B.; Jayakrishnan, A. Self-cross-linking biopolymers as injectable in situ forming biodegradable scaffolds. Biomaterials 2005, 26, 3941-3951.

[41] Fellah, B. H.; Weiss, P.; Gauthier, O.; Rouillon, T.; Pilet, P.; Daculsi, G.; Layrolle, P. Bone repair using a new injectable self-crosslinkable bone substitute. J. Orthop. Res. 2006, 24, 628635.

[42] Shin, H.; Ruhe, P. Q.; Mikos, A. G.; Jansen, J.A. In vivo bone and soft tissue response to injectable, biodegradable oligo(poly(ethylene glycol) fumarate) hydrogels. Biomaterials 2003, 24, 3201-3211.

[43] Bastiancich, C.; Vanvarenberg, K.; Ucakar, B.; Pitorre, M.; Bastiat, G.; Lagarce, F.; Préat, V.; Danhier, F. Lauroyl-gemcitabine-loaded lipid nanocapsule hydrogel for the treatment of glioblastoma. J. Control Release 2016, 225, 283-293.

[44] Torge, A.; Wagner, S.; Chaves, P.S.; Oliveira, E. G.; Guterres, S. S.; Pohlmann, A. R.; Titz, A.; Schneider, M.; Beck, R. C. R. Ciprofloxacin-loaded lipid-core nanocapsules as mucus penetrating drug delivery system intended for the treatment of bacterial infections in cystic fibrosis. Int. J. Pharm. 2017, 527(1-2), 92-102.

[45] Nguyen, H. T. P.; Munnier, E.; Perse, X.; Vial, F.; Yvergnaux, F.; Perrier, T.; Souce, M.; Chourpa, I. Qualitative and quantitative study of the potential of lipid nanocapsules of one hundred twenty nanometers for the topical administration of hydrophobic molecules. J. Pharm. Sci, 2016, 105(10), 3191-3198.

[46] Wauthoz, N.; Bastiat, G.; Moysan, E.; Cieślak, A.; Kondo, K.; Zandecki, M.; Moal, V.; Rousselet, J. M.; Hureaux, C.; Benoit, J. P. Safe lipid nanocapsule-based gel technology to target lymph nodes and combat mediastinal metastases from an orthotopic non-small-cell lung cancer model in SCID-CB17 mice. Nanomed. Nanotechnol. 2015, 11(5), 1237-1245.

[47] Kim, J. Il.; Lee, B. S.; Chun, C. J.; Cho, J. K.; Kim, S. Y.; Song, S. C. Long-term theranostic hydrogel system for solid tumors. Biomaterials 2012, 33(7), 2251-2259.

[48] Podgórnaa, K.; Szczepanowicz, K.; Piotrowski, M.; Gajdosová, M.; St epánek, F.; Warszynski, P. Gadolinium alginate nanogels for theranostic applications. Colloids. Surf. B Biointerfaces. 2017, 153, 183-189.

[49] Eroglu, M. S.; Guven, O. Characterization of network structure of Poly(glycidyl azide) elastomers by swelling, solubility and mechanical measurements. Polymer 1998, 39(5), 1173 1176.

[50] Eroglu, M. S. Characterization of the network structure of hydroxyl terminated Poly(butadiene) elastomers prepared by different reactive systems. J. Appl. Polym. Sci. 1998, 70, 1129-1135. 
[51] Yoo, J. Y.; Kim, M.; Lee, J. Electrospraying of micro/nano particles for protein drug delivery. Polym. Kor. 2007, 31, 215-220.

[52] Zhang, S. L.; Kawakami, K. One-step preparation of chitosan solid nanoparticles by electrospray deposition. Int. J. Pharm. 2010, 397, 211-217.

[53] Pancholi, K.; Ahras, N.; Stride, E.; Edirisinghe, M. Novel electrohydrodynamic preparation of porous chitosan particles for drug delivery. J. Mater. Sci. Mater. Med. 2009, 20, 917-923.

[54] Pina, M. F.; Lau, W.; Scherer, K.; Parhizkar, M.; Edirisinghe, M.; Craig, D. The generation of compartmentalized nanoparticles containing siRNA and cisplatin using a multi-needle electrohydrodynamic strategy. Nanoscale 2017, 9, 5975-5985.

[55] Ahmad, B.; Gunduz, O.; Stoyanov, S.; Pelan, E.; Stride, E.; Edirisinghe, M. A novel hybrid system for the fabrication of a fibrous mesh with micro-inclusion. Carbohydr. Polym. 2012, 89, 222-229.

[56] Husain, O.; Lau, W.; Edirisinghe, M.; Parhizkar, M. Investigating the particle to fiber transition threshold during electrohydrodynamic atomization of a polymer solution. Mater. Sci. Eng. C. Mater. Biol. Appl. 2016, 65, 240-250.

[57] Muzzarelli, R. A. A.; Mehtedi, M.; Bottegoni, C.; Aquili, A.; Gigante, A. Genipin-Crosslinked chitosan gels and scaffolds for tissue engineering and regeneration of cartilage and bone. Mar. Drugs. 2015, 13, 7314-7338.

[58] Asran, A. S.; Henning, S.; Michler, G. H. Polyvinyl alcohol-collagen-hydroxyapatite biocomposite nanofibrous scaffold: Mimicking the key features of natural bone at the nanoscale level. Polymer 2010, 51, 868-876.

[59] Ji, Y.; Ghosh, K.; Li, B. Q.; Sokolov, J. C.; Clark, R. A. F.; Rafailovich, M. H. Dual-syringe reactive electrospinning of cross-linked hyaluronic acid hydrogel nanofibers for tissue engineering applications. Macromol. Biosci. 2006, 6, 811-817.

[60] Chen, J. M.; Liu, Z. G.; Chen, M. H.; Zhang, H.; Li, X. H. Electrospun gelatin fibers with a multiple release of antibiotics accelerate dermal regeneration in infected deep burns. Macromol.Biosci. 2016, 16, 1368-1380.

[61] Xu, Y. F.; Wang, X. H. Application of 3D biomimetic models in drug delivery and regenerative medicine. Curr. Pharm. Des. 2015, 21, 1618-1626.

[62] Sridhar, S.; Venugopal, J. R.; Ramakrishna, S. Improved regeneration potential of fibroblasts using ascorbic acid-blended nanofibrous scaffolds. J. Biomed. Mater. Res. A 2015, 103, 34313440 .

[63] Park, J. Y.; Kyung, K. H.; Tsukada, K.; Kim, S. H.; Shiratori, S.; Biodegradable polycaprolactone nanofibers with beta-chitosan and calcium carbonate produce a hemostatic effect. Polymer 2017, 123, 194-202.

[64] Li, X.; Cui, R.; Sun, L.; Aifantis, K. E.; Fan, Y.; Feng, Q.; Cui, F.; Watari, F. 3D printed biopolymers for tissue engineering applications. Int. J. Polym. Sci. 2014, 2014, Article ID 82914513 pages.

[65] Li, W.-J.; Tuli, R.; Okafor, C.; Derfoul, A.; Danielson, KG.; Hall, DJ.; Tuan, RS. A threedimensional nanofibrous scaffold for cartilage tissue engineering using human mesenchymal stem cells. Biomaterials 2005, 26(6), 599-609.

[66] Rodrigues, A. I.; Gomes, M. E.; Leonor, I. B.; Reis, R. L. Bioactive starch-based scaffolds and human adipose stem cells are a good combination for bone tissue engineering. Acta. Biomater. 2012, 8, 3765-3776.

[67] Hu, J.; Sun, X.; Ma, H.; Xie, C.; Chen,Y. E.; Ma, P. X. Porous nanofibrous PLLA scaffolds for vascular tissue engineering. Biomaterials 2010,31(31), 7971-7977.

[68] Hasan, A.; Memic, A.; Annabi, N.; Hossain, M.; Paul, A.; Dokmeci, M. R.; Dehghani, F.; Khademhosseini, A. Electrospun scaffold for tissue engineering of vascular graft. Acta Biomater. 2014, 10, 11-25.

[69] Ghasemi-Mobarakeh, L.; Prabhakaran, M. P.; Morshed, M.; Nasr-Esfahani, M. H.; Ramakrishna, S. Electrospun-poly( $\varepsilon$ caprolactone)/gelatin nanofibrous scaffolds for nerve tissue engineering. Biomaterials 2008, 29(34), 4532 - 4539.

[70] Pattison, M. A.; Wurster, S.; Webster, T. J.; Haberstroh, K. M. Three-dimensional, nanostructured PLGA scaffolds for bladder tissue replacement applications. Biomaterials. 2005, 26(15), 2491-2500.

[71] Li, X.; Feng, Q.; Liu, X.; Dong, W.; Cui, F. Collagen-based implants reinforced by chitin fibers in a goat shank bone defect model. Biomaterials 2006, 27(9), 1917-1923.

[72] Serrano, M. C.; Nardecchia, S.; Garcia-Rama C., Ferrer, M. L.; Collazos-Castro, J. E.; Monte, F.; Gutierrez, M. C. Chondroitin sulphate-based 3D scaffolds containing MWCNTs for nervous tissue repair. Biomaterials 2014, 35, 1543-1551. 
[73] Tamura, H.; Furuike, T.; Nair, S.V.; Jayakumar, R. Biomedical applications of chitin hydrogel membranes and scaffolds. Carbohydr. Polym. 2011, 84(2), 820-824.

[74] Islam, A.; Yasin, T.; Rehman, I. Synthesis of hybrid polymer networks of irradiated chitosan/poly(vinyl acohol) for biomedical applications. Phys. Chem. 2014, 96, 115-119.

[75] Sousa, I.; Mendes, A.; B' artolo, P. J. PCL scaffolds with collagen bioactivator for applications in tissue engineering. Procedia. Eng. 2013, 59, 79-284.

[76] Chen, G.; Tanaka, J.; Tateishi, T. Osteochondral tissue engineering using a PLGA-collagen hybrid mesh. Mater. Sci. Eng. C 2006, 26(1), 124-129.

[77] Zhang, C.; Sangaj, N.; Hwang, Y.; Phadke, A.; Chang, C.-W.; Varghese, S. Oligo(trimethylene carbonate) poly(ethyleneglycol) oligo(trimethylene carbonate) triblock-based hydrogels for cartilage tissue engineering. Acta Biomater. 2011, 7(9), 3362-3369.

[78] Zhou, X.; Nowicki, M.; Cui, H. T.; Zhu, W.; Fang, X. Q.; Miao, S. D.; Lee, S. J.; Keidar, M.; Zhang, LG. 3D bioprinted graphene oxide-incorporated matrix for promoting chondrogenic differentiation of human bone marrow mesenchymal stem cells. Carbon 2017, 116, 615-624.

[79] Zhai, X. Y.; Ma, Y. F.; Hou, C. Y.; Gao, F.; Zhang, Y. Y.; Ruan, C. S.; Pan, H.; Lu, W. W.; Liu, W. 3D-Printed high strength bioactive supramolecular polymer/clay nanocomposite hydrogel scaffold for bone regeneration. Acs. Biomater. Sci. Eng. 2017, 3, 1109-1118.

[80] Tao, J.; Zhang, J. M.; Hu, Y.; Yang, Y.; Gou, Z. Y.; Du, T.; Mao, J.; Gou, M. A conformal hydrogel nanocomposite for local delivery of paclitaxel. J. Biomater. Sci. Polym. Ed. 2017, 28, 107-118.

[81] Bendtsen, S. T.; Quinnell, S. P.; Wei, M. Development of a novel alginate-polyvinyl alcoholhydroxyapatite hydrogel for 3D bioprinting bone tissue engineered scaffolds. J. Biomed. Mater. Res. A 2017, 105, 1457-1468.

[82] Leppiniemi, J.; Lahtinen, P.; Paajanen, A.; Mahlberg, R.; Metsa-Kortelainen, S.; Pinornaa, T.; Pajari, H.; Vikholm-Lundin, I.; Pursula, P.; Hytönen, VP. 3D-Printable bioactivated nanocellulose-alginate hydrogels. Acs Appl. Mater. Interfaces 2017, 9, 21959-21970.

[83] Baumann, B.; Jungst, T.; Stichler, S.; Feineis, S.; Wiltschka, O.; Kuhlmann, M.; Linden, M.; Groll, J. Control of nanoparticle release kinetics from 3D printed hydrogel scaffolds. Angew. Chem. Int. Ed. 2017, 56, 4623-4628.

[84] Duan, B.; Hockaday, L. A.; Kang, K. H.; Butcher, J. T. 3D Bioprinting of heterogeneous aortic valve conduits with alginate/gelatin hydrogels. J. Biomed. Mater. Res. A, 2013, 101, 1255-1264.

[85] Riahi, R.; Tamayol, A., Mousavi Shaegh, S. A.; Ghaemmaghami, A. M.; Dokmeci, M R.; Khademhosseini, A. Microfluidics for advanced drug delivery systems. Curr. Opin. Chem. Eng. 2015, 7, 101-112.

[86] Kochhar, J. S.; Goh, W. J.; Chan, S. Y.; Kang, L. A simple method of microneedle array fabrication for transdermal drug delivery. Drug Dev. Ind. Pharm. 2013, 39, 299-309.

[87] Lo, C. T.; Jahn, A.; Locascio, L. E.; Vreeland, W. N. Controlled self-assembly of monodisperseniosomes by microfluidic hydrodynamic focusing. Langmuir 2010, 26, 8559-8566.

[88] LaVan, D. A.; McGuire, T.; Langer, R. Small-scale systems for in vivo drug delivery. Nat. Biotechnol. 2003, 21, 1184-1191.

[89] Lo, R.; Li, P. Y.; Saati, S.; Agrawal, R.; Humayun, M.; Meng, E. A passive MEMS drug delivery pump for treatment of ocular diseases. Biomed. Microdev. 2009, 11, 959-970.

[90] Tendulkar, S.; Mirmalek-Sani, S. H.; Childers, C.; Saul, J.; Opara, E. C.; Ramasubramanian, MK. A three-dimensional microfluidic approach to scaling up microencapsulation of cells. Biomed. Microdevice, 2012, 14, 461-469.

[91] Moya, M. L.; Cheng, M. H.; Huang, J. J.; Francis-Sedlak, M. E.; Kao, S. W.; Opara, E. C.; Brey, E. M. The effect of FGF-1 loaded alginate microbeads on neovascularization and adipogenesis in a vascular pedicle model of adipose tissue engineering. Biomaterials 2010, 31, 2816-2826.

[92] Moya, M. L.; Opara, E. C.; Greisler, H. P.; Brey, E. M. Optimizing alginate microbead formulation for sustained release of angiogenic protein for neovascularization of islet grafts. Diabetes 2007, 56(A), A717-A718.

[93] Moya, M. L.; Morley, M.; Khanna, O.; Opara, E. C.; Brey, EM. Stability of alginate microbead properties in vitro. J. Mater. Sci. Mater. Med. 2012, 23, 903-912.

[94] Rezvanpour, A.; Krantz, W. B.; Wang. C. H. Scaling analysis of the electrohydrodynamic atomization (EHDA) process for pharmaceutical particle fabrication. Chem. Eng. Sci. 2012, 80, 81-90.

[95] Zhang, S.; Kawakami, K. One-step preparation of chitosan solid nanoparticles by electrospray deposition. Int. J. Pharm. 2010, 397, 211-217.

[96] Xie, J. W.; Lim, L. K.; Phua, Y. Y.; Hua, J. S.; Wang, C. H. Electrohydrodynamic atomization for biodegradable polymeric particle production. J. Colloid Interface Sci. 2006, 302, 103-112. 
[97] Abbadessaa, A.; Blokzijl, M. M.; Mouser, V. H. M.; Maricaa, P.; Malda, J.; Henninka, W. E. A thermo-responsive and photo-polymerizable chondroitin sulfate-based hydrogel for 3D printing applications. Carbohydr. Polym. 2016, 149, 163-174.

[98] Zhuang, Y.; Song, W.; Ning, G.; Sun, X.; Sun, Z.; Xu, G.; Zhang, B.; Chen, Y.; Tao, S. 3Dprinting of materials with anisotropic heat distribution using conductive polylactic acid composites. Mater. Design 2017, 126, 135-140.

[99] Lee, J. Y.; An, J.; Chua, C. K. Fundamentals and applications of 3D printing for novel materials. App. Mater. Today. 2017, 7, 120-133.

[100] Liu,Y.; Meng, L.; Lu, X.; Zhang, L.; He, Y. Thermo and pH sensitive fluorescent polymer sensor for metal cations in aqueous solution. Polym. Adv. Technol. 2008, 19, 137-143.

[101] Crespy, D.; Rossi, R. M. Temperatureresponsive polymers with LCST in the physiological range and their applications in textiles. Polym. Int., 2007, 56, 1461-1468.

[102] $\mathrm{Hu}, \mathrm{J} . ; \mathrm{Li}, \mathrm{C} . ; \mathrm{Liu}, \mathrm{S} . \mathrm{Hg}^{2+}$-reactive double hydrophilic block copolymer assemblies as novel multifunctional fluorescent probes with improved performance. Langmuir 2009, 26, 724-729.

[103] Doi, M.; Matsumoto, M.; Hirose, Y. Deformation of ionic polymer gels by electric fields. Macromolecules 1992, 25, 5504-5511.

[104] Jin, X.; Kang, H.; Huang, Y.; Liu, H.; Hu, Y. Synthesis and properties of electricallysensitive poly(acrylic-acid-co-acetoacetoxy-ethy-methacrylate) gels. J. Appl. Polym. Sci. 2008, 110, 3690-3696.

[105] Adesanya, K.; Vanderleyden, E.; Embrechts, A.; Glazer, P.; Mendes, E.; Dubruel, P. Properties of electrically responsive hydrogels as a potential dynamic tool for biomedical applications. $J$. Appl. Polym. Sci. 2014, 131, 205-212.

[106] Jochum, F. D.; Zur Borg, L.; Roth, P. J.; Theato, P. Thermo- and light-responsive polymers containing photoswitchable azobenzene end groups. Macromolecules 2009, 42, 7854-7862.

[107] Beharry, A. A.; Woolley, G. A. Azobenzene photoswitches for biomolecules. Chem. Soc. Rev. 2011, 40, 4422-4437.

[108] Rini, M.; Holm, A. K.; Nibbering, E. T.; Fidder, H. Ultrafast UV-mid-IR investigation of the ring opening reaction of a photochromic spiropyran. J. Am. Chem. Soc. 2003, 125, 3028-3034.

[109] Hirakura, T.; Nomura, Y.; Aoyama, Y.; Akiyoshi, K. Photoresponsive nanogels formed by the self-assembly of spiropyrane-bearing pullulan that act as artificial molecular chaperones. Biomacromolecules 2004, 5, 1804-1809.

[110] Han, P.; Li, S.; Wang, C.; Xu, H.; Wang, Z.; Zhang, X.; Thomas, J.; Smet, M. UV-responsive polymeric superamphiphile based on a complex of malachite green derivative and a double hydrophilic block copolymer. Langmuir 2011, 27, 14108-14111.

[111] Li, Y.; Wang, M.; White, T. J.; Bunning,T. J.; Li,Q. Azoarenes with opposite chiral configurations: lightdriven reversible handedness inversion in self-organized helical superstructures. Angew. Chem. Int. Ed. 2013, 52, 8925-8929.

[112] Zhao, W.; Fang, B.; Li, N.; Nie, S.; Wei, Q.; Zhao, C. Fabrication of pHresponsive molecularly imprinted polyethersulfone particles for bisphenolA uptake. J. Appl. Polym. Sci., 2009, 113, 916921.

[113] Abdelaal, M.; AbdelRazik, E.; AbdelBary, E.; ElSherbiny, I. Chitosanbased interpolymeric pHresponsive hydrogels for in vitro drug release. J. Appl. Polym. Sci. 2007, 103, 2864-2874.

[114] Wang, H.; Tan, B.; Wang, J.; Li, Z.; Zhang,S. Anion-based pH responsive ionic liquids: design, synthesis, and reversible self-assembling structural changes in aqueous solution. Langmuir 2014, 30, 3971-3978.

[115] Wang, D.; Wu, T.; Wan, X.; Wang, X.; Liu, S. Purely salt-responsive micelle formation and inversion based on a novel schizophrenic sulfobetaine block copolymer: structure and kinetics of micellization. Langmuir 2007, 23, 11866-11874.

[116] Whittell, G. R.; Hager, M. D.; Schubert, U. S. I. Manners, Functional soft materials from metallopolymers and metallosupramolecular polymers. Nat. Mater. 2011, 10, 176-188.

[117] Cohen, S.; Yoshioka, T.; Lucarelli, M.; Hwang, L. H.; Langer, R. Controlled delivery systems for proteins based on poly(lactic/glycolic acid) microspheres. Pharm. Res. 1991, 8, 713-720.

[118] Chen, J. K.; Hsieh, C. Y.; Huang, C. F.; Li, P. M. Characterization of patterned poly(methyl methacrylate) brushes under various structures upon solvent immersion. J. Colloid Interface Sci. 2009, 338, 428-434.

[119] Draper, J.; Luzinov, I.; Minko, S.; Tokarev, I.; Stamm, M.; Mixed polymer brushes by sequential polymer addition: anchoring layer effect. Langmuir 2004, 20, 4064-4075.

[120] Velez, C.; Torres-Díaz, I.; Maldonado-Camargo, L.; Rinaldi, C.; Arnold, D. P. Magnetic assembly and cross-linking of nanoparticles for releasable magnetic microstructures. ACS Nano 2015, 9, 10165-10172. 
[121] Yoo, D.; Lee, J. H.; Shin, T. H.; Cheon, J. Theranostic magnetic nanoparticles, Acc. Chem. Res. 2011, 44, 863-874.

[122] Hong, F.; Yan, C.; Si, Y.; He, J.; Yu, J.; Ding, B. Nickel ferrite nanoparticles anchored onto silica nanofibers for designing magnetic and flexible nanofibrous membranes. ACS Appl. Mater. Interfaces 2015, 7, 20200-20207.

[123] Hu, Y.; Wang, J.; Wang, H.; Wang, Q.; Zhu, J.; Yang, Y. Microfluidic fabrication and thermoreversible response of core/shell photonic crystalline microspheres based on deformable nanogels. Langmuir 2012, 28, 17186-17192.

[124] Li, B.; Smilgies, D. M.; Price, A. D.; Huber,D. L.; Clem, P. G.; Fan, H. Poly(Nisopropylacrylamide) surfactant-functionalized responsive silver nanoparticles and superlattices. ACS Nano 2014, 8, 4799-4804.

[125] Pavlichenko, I.; Exner, A. T.; Guehl, M.; Lugli, P.; Scarpa, G.; Lotsch, B. V. Humidity-enhanced thermally tunable $\mathrm{TiO}_{2} / \mathrm{SiO}_{2}$ bragg stacks. J. Phys. Chem. C 2011, 116, 298-305.

[126] Ma, P. C.; Liu, M. Y.; Zhang, H.; Wang, S. Q.; Wang, R.; Wang, K.; Wong, YK.; Tang, BZ.; Hong, SH.; Paik, KW.; Kim, JK. Enhanced electrical conductivity of nanocomposites containing hybrid fillers of carbon nanotubes and carbon black. ACS Appl. Mater. Interfaces 2009, 1, 10901096.

[127] Ge, J.; Neofytou, E.; Cahill III, T. J.; Beygui, R. E.; Zare, R. N. Drug release from electric-fieldresponsive nanoparticles. ACS Nano 2011, 6, 227-233.

[128] Fazal, S.; Jayasree, A.; Sasidharan, S.; Koyakutty, M.; Nair, S. V.; Menon, D. Green synthesis of anisotropic gold nanoparticles for photothermal therapy of cancer. ACS Appl. Mater. Interfaces 2014, 6, 8080-8089.

[129] Zhang, X.; Xu, X.; Li, T.; Lin, M.; Lin, X.; Zhang, H.; Sun, H.; Yang, B. Composite photothermal platform of polypyrrole-enveloped $\mathrm{Fe}_{3} \mathrm{O}_{4}$ nanoparticle self-assembled superstructures. ACS Appl. Mater. Interfaces 2014, 6, 14552-14561.

[130] Hemamalini, T.; Giri Dev, V. R. Comprehensive review on electrospinning of starch polymer for biomedical applications. Inter. J. Biol. Macromol. 2018, 106, 712-718.

[131] Agarwal, S.; Greiner, A.; Wendorff, J.H. Functional materials by electrospinning of polymers. Prog. Polym. Sci. 2013, 38, 963-991.

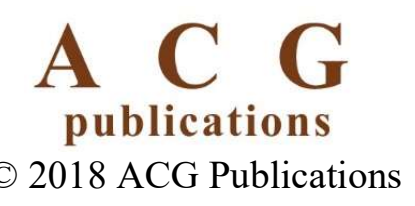

